7. Reprod. Fert. (1974) 39, 319-327

\title{
INTERRUPTION OF PREGNANCY IN RATS BY VARIOUS FLUOROANDROSTANE DERIVATIVES
}

\author{
Y. TACHÉ AND J. TACHÉ \\ Institut de Médecine et de Chirurgie Expérimentales, \\ Université de Montréal, Montreal 101, Quebec, Canada
}

(Received 17th September 1973)

Summary. In the rat, pregnancy was affected by androstane derivatives (including three 9 $\alpha$-fluoro-4-androsten-3-one, 11-and 17-substituted), given orally in doses of $5 \mathrm{mg} / 100 \mathrm{~g}$ body weight from Days 3 to 10 . Fluorohydroxyandrostenedione (FHA) and fluoxymesterone appeared to be $100 \%$ effective in suppressing fertility, while steroid U-6596 seriously disturbed gestation though not in all cases. Under similar experimental conditions, the abortifacient activity of FHA, fluoxymesterone and steroid U-6596 was respectively abolished, decreased or left unaltered after substitution of $9 \alpha$-fluorine by hydrogen. The $5 \beta$ saturated homologues of FHA and fluoxymesterone, as well as $9 \alpha-$ fluoro-17 $\alpha$-methyl-5 $\beta$-androstane-3 $\alpha, 11 \beta, 17$-triol, were totally ineffective in interrupting pregnancy. The relative antifertility potency of the fluorosteroids in rats roughly paralleled their uterotrophic activity in immature mice.

Comparative studies showed that FHA (administered at the 5-mg dose level but from the 3rd to the 7th day of pregnancy) was more effective than the other two fluoroandrostenes tested. The abortifacient action of FHA was reduced when the dosage was decreased, the minimum $100 \%$ effective oral dose being $2.5 \mathrm{mg} / 100 \mathrm{~g}$ body weight. In addition, this fluorosteroid also exerted some interceptive activity.

Progesterone abolished the abortifacient effect of $2 \cdot 5$, but not of $5 \mathrm{mg}$, of FHA. Under identical conditions, prolactin had no such protective influence.

\section{INTRODUCTION}

When given orally during early pregnancy, CS-1 (Catatoxic Steroid No. 1 or $9 \alpha$-fluoro-1 $1 \beta, 17$-dihydroxy-3-oxo-4-androstene-17 $\alpha$ propionic acid potassium salt-Searle: SC-11927), a steroid devoid of androgenic, oestrogenic or antioestrogenic properties (Drill, 1960), totally prevents implantation in rats. This effect seems to be mediated through a prolactin deficiency (Selye, Taché \& Szabo, 1971; Taché, Taché \& Selye, 1974). In the present work, part of which has been reported in abstract form (Taché \& Selye, 1973), we have extended our studies to a series of $9 \alpha$-fluoroandrostane derivatives to screen their antifertility activity. One of these compounds, fluorohydroxyandrostenedione (FHA), proved to be very potent in this respect; hence, it was 
tested more extensively to determine whether its effect was associated with hormonal disturbances in the body. The possibility of 'structure-activity' relationships of these steroids was also examined.

\section{MATERIALS AND METHODS}

For all our experiments, we used Sprague-Dawley rats (Canadian Breeding Farms \& Laboratories Ltd, St Constant, Quebec, Canada) with an initial mean body weight of $185 \mathrm{~g}$ (160 to $210 \mathrm{~g}$ ). Each animal was kept in a separate cage and allowed free access to Purina Laboratory Chow and tap water. Insemination was determined by the identification of spermatozoa in the vagina (Day 1 of pregnancy). The presence of implantation sites was checked on the 9th day by direct inspection of the uterus through a small laparotomy incision. From the 13th day, pregnancy was verified by palpation and weight gain.

Unless otherwise stated, the animals were killed on the 21st day of pregnancy, when the number of implantation sites and living fetuses was recorded. If no live fetuses were found in utero, pregnancy was considered to have been interrupted, and the percentage was calculated as the number of interruptions/total number of treated rats.

The test compounds were administered at the dose levels indicated in the tables per $100 \mathrm{~g}$ body weight (in $1 \mathrm{ml}$ aqueous suspensions homogenized with a few drops of Tween 80) twice daily by stomach tube.

In the first experiment, sixty-six rats were allocated to ten groups, of which one served as a control. The others received $5 \mathrm{mg}$ of the steroids (listed in Table 1 ) from Days 3 to 10 of pregnancy.

In the second experiment (Table 2), the uterotrophic activity of the fluorosteroids was determined by the method of Rubin, Dorfman, Black \& Dorfman (1951), using immature Charles River GD-1 mice. The steroids were administered subcutaneously, in a dose of $100 \mu \mathrm{g}$ in $0.1 \mathrm{ml}$ peanut oil, daily for 3 days. Oestrone $(0.10 \mu \mathrm{g})$ was used as a standard. Body and uterine wet weights were recorded at autopsy ( $24 \mathrm{hr}$ after the last injection). The uterus ratio was calculated as one hundred times the uterus weight $(\mathrm{mg})$ divided by the body weight (g).

In the third experiment (Table 3 ), three $9 \alpha$-fluorosteroids, FHA, fluoxymesterone and U-6596 (shown to be active in interfering with pregnancy), were administered as described in the first experiment but for 5 consecutive days, from the 3rd day of pregnancy.

In the fourth experiment (Table 4), thirty-three rats were allocated to five groups. To determine whether FHA (5 $\mathrm{mg}$ ) was active after implantation, treatment of Group 2 was started on Day 9 of pregnancy, and was continued through Day 14. Groups 3 to 5 received various doses of FHA for 5 or 8 days (from Day 3 of pregnancy). Fetal weight was recorded at autopsy.

In the fifth experiment (Table 5), forty-four rats were allocated to six groups, five of which were given 2.5 or $5 \mathrm{mg}$ FHA. Progesterone (Roussel) was administered subcutaneously in $0.2 \mathrm{ml}$ peanut oil at the dose of $6 \mathrm{mg} / \mathrm{rat} / \mathrm{day}$. Prolactin (Ferring AG) was injected subcutaneously twice daily: 2.5 or 1 
$\mathrm{mg} / 100 \mathrm{~g}$ body weight in $0.4 \mathrm{ml}$ water. Treatment with these three compounds was initiated on Day 3 of pregnancy, and lasted for 5 days.

For histological examination, six animals given the minimal $100 \%$ effective dose of FHA from Days 3 to 7, as well as an equal number of untreated pregnant controls, were killed on the 8th day of gestation. Their ovaries and uteri were fixed in a Susa solution saturated with picric acid, and stained according to the periodic acid-Schiff (PAS) technique.

All the results were statistically evaluated by Student's $t$ test.

\section{RESULTS}

Experiment 1. As shown in Table 1, FHA and fluoxymesterone totally inhibited the development of term fetuses in all animals of Groups 2 and 3. Laparotomy on the 9th day and autopsy on the 21st day revealed empty uterine horns, lacking all signs of implantation. Steroids U-6596, U-5437 and U-4407 (Groups 4, 6 and 7) suppressed fertility in a significant number of rats; when pregnancy continued despite treatment, we noted some deleterious effects on the number of implantation sites and fetuses compared to those of the controls. Steroids U-2826, U-6796, U-7033 and U-7034 (Groups 5, 8, 9 and 10) did not adversely affect the progress of gestation.

Experiment 2. Table 2 illustrates the effect of the fluorosteroids on uterine weight in immature mice. The mean uterine ratio of the controls was 98 . Daily administration of oestrone $(0.10 \mu \mathrm{g})$ resulted in a ratio of 415 . All the three $9 \alpha$-fluoro-4-androstene derivatives provoked a significant positive response at the $100-\mu \mathrm{g}$ dose level. Under identical conditions, two $9 \alpha$-fluoro$5 \beta$-androstane derivatives caused no significant increase in the uterine ratio.

Experiment 3. As indicated in Table 3, pregnancy was invariably interrupted by daily administration of FHA (5 mg) from Days 3 to 7 (Group 2). Fluoxymesterone and steroid U-6596 did not significantly decrease the incidence of pregnancy or the number of implantation sites but survival of the implanted embryos was affected in these animals (Groups 3 and 4).

In the light of the above results, FHA appeared to be the most potent member of this series as regards post-coital antifertility activity. Further study was therefore considered necessary to determine if FHA interrupted pregnancy after implantation and if its antifertility effect was associated with hormonal disturbances in the body.

Experiment 4. Daily treatment with $5 \mathrm{mg}$ FHA (from the 9th to the 14th day) caused a few complete abortions (Table 4, Group 2). In animals that remained pregnant, there was a high percentage of fetal resorption. The live fetuses of this group were significantly smaller than those of the controls, but showed no gross developmental defects.

From the results presented in Table 4, it can be seen that $2.5 \mathrm{mg}$ FHA was the minimum 100\% effective dose (Group 3). At the 1-mg dose level, this fluorosteroid prevented pregnancy in $50 \%$ of the rats; the number of implantation sites was normal in the remaining pregnant animals, but the course of pregnancy was considerably impaired, as shown by a high mortality rate among the fetuses. Pregnancy was not modified by $0.5 \mathrm{mg}$ FHA. 
Table 1. Interruption of pregnancy in rats by various fluoroandrostane derivatives

\begin{tabular}{|c|c|c|c|c|c|c|}
\hline \multirow{3}{*}{ Group } & \multirow{3}{*}{$\begin{array}{l}\text { No. } \\
\text { of } \\
\text { rats }\end{array}$} & \multirow{3}{*}{$(5 \mathrm{mg} / 100 \mathrm{~g}$ body wt from } & \multirow{3}{*}{$\begin{array}{l}\text { Steroids } \\
\text { the } 3 r d \text { to the } 10 \text { th day of pregnancy) }\end{array}$} & \multicolumn{3}{|c|}{ Pregnancy } \\
\hline & & & & \multirow{2}{*}{$\begin{array}{c}\text { Inter- } \\
\text { ruption } \\
(\%)\end{array}$} & \multicolumn{2}{|c|}{ Maintenance } \\
\hline & & & & & $\underset{\text { implantations/rat } \dagger}{\text { No. of }}$ & $\begin{array}{c}\text { No. of } \\
\text { fetuses/rat } \dagger\end{array}$ \\
\hline 1 & 11 & & Untreated & 0 & $11 \cdot 0 \pm 0.9$ & $9 \cdot 7 \pm 0.8$ \\
\hline 2 & 7 & & $\begin{array}{l}9 \alpha \text {-Fluoro-11 } \beta \text {-hydroxy-4- } \\
\text { androstene-3,17-dione } \\
\text { Fluorohydroxyandrostenedione } \\
\text { (FHA or U-5438) } \\
\text { (Lederle, Upjohn) }\end{array}$ & 100 & N.A. & N.A. \\
\hline 3 & 7 & & $\begin{array}{l}\text { dinyaroxy-4-androsten-3-one } \\
\text { Fluxymesterone (U-6040) } \\
\text { (Upjohn) }\end{array}$ & 100 & N.A. & N.A. \\
\hline 4 & 7 & & $\begin{array}{l}\text { hydroxy-4-androstene-3,11- } \\
\text { dione (U-6596) } \\
\text { (Upjohn) }\end{array}$ & 57 & $4 \cdot 7 \pm 0 \cdot 9 * * *$ & $2 \cdot 7 \pm 1 \cdot 2 * * *$ \\
\hline 5 & 6 & & $\begin{array}{l}\text { 11 } \beta \text {-Hydroxy-4-androsten- } \\
\text { 3,17-dione (U-2826) } \\
\text { (Upjohn) }\end{array}$ & 0 & $9 \cdot 3 \pm 1 \cdot 3$ N.S. & $7 \cdot 8 \pm 1 \cdot 3$ N.S. \\
\hline 6 & 7 & & $\begin{array}{l}\text { 17 } \alpha \text {-Methyl-11 } \beta, 17 \text {-dihydroxy- } \\
\text { 4-androsten-3-one (U-5437) } \\
\text { (Upjohn) }\end{array}$ & 71 & $7 \cdot 0 \pm 0 \cdot 0 * * *$ & $6 \cdot 0 \pm 0 \cdot 0^{* * *}$ \\
\hline 7 & 7 & & $\begin{array}{l}17 \beta \text {-Hydroxy-17-methyl-4- } \\
\text { androstene-3,11-dione (U-4407) } \\
\text { (Upjohn) }\end{array}$ & 57 & $5 \cdot 3 \pm 1 \cdot 3 * * *$ & $1 \cdot 7 \pm 0 \cdot 3 * * *$ \\
\hline 8 & 4 & & $\begin{array}{l}\text { 17-methyl-5 } \beta \text {-androstan- } \\
\text { 3-one (U-6796) } \\
\text { (Upjohn) }\end{array}$ & 0 & $11 \cdot 3 \pm 1 \cdot 0$ N.S. & $10 \cdot 5 \pm 1 \cdot 7$ N.S. \\
\hline 9 & 6 & & $\begin{array}{l}\text { hydroxy-J } \beta \text {-androstane- } \\
\text { 3,11-dione (U-7033) } \\
\text { (Upjohn) }\end{array}$ & 33 & $10 \cdot 8 \pm 0 \cdot 8$ N.S. & $9 \cdot 3 \pm 0.6$ N.S. \\
\hline 10 & 4 & & $\begin{array}{l}9 \alpha \text {-Fluoro-17 } \alpha \text {-methyl-5 } \beta \text { - } \\
\text { androstane-3 } \alpha, 11 \beta, 17 \text {-triol } \\
\text { (U-7034) } \\
\text { (Upjohn) }\end{array}$ & 0 & $12 \cdot 3 \pm 0.6$ N.S. & $11 \cdot 3 \pm 1 \cdot 3$ N.S. \\
\hline
\end{tabular}


Experiment 5. Progesterone $(6 \mathrm{mg})$ did not protect against the antifertility effect of $5 \mathrm{mg} \mathrm{FHA}$, given from the 3rd to the 7 th day of pregnancy (Table 5 , Group 2) but normal litters were noted in $78 \%$ of the animals simultaneously treated with $2.5 \mathrm{mg} \mathrm{FHA}$ and $6 \mathrm{mg}$ progesterone (Group 3). Under similar conditions, prolactin $(1 \mathrm{or} 2.5 \mathrm{mg}$ ) did not reverse the action of FHA (Groups $4,5$ and 6$)$.

Table 2. Effect of fluoroandrostane steroids on the uterine weight of immature mice

\begin{tabular}{|c|c|c|}
\hline Steroids & No. of mice & $\begin{array}{l}\text { Uterus } \\
\text { ratio } †\end{array}$ \\
\hline - & $\begin{array}{l}12 \\
13\end{array}$ & $\begin{array}{l}98 \pm 4 \\
415 \pm 21 * * *\end{array}$ \\
\hline $\begin{array}{l}9 \alpha \text {-Fluoro-11 } \beta \text {-hydroxy-4- } \\
\text { androstene- } 3,17 \text {-dione (FHA) }\end{array}$ & 10 & $184 \pm 12 * * *$ \\
\hline $\begin{array}{l}\text { 9 } \alpha \text {-Fluoro- } 17 \alpha \text {-methyl-11 } \beta, 17- \\
\quad \text { dihydroxy-4-androsten-3-one }\end{array}$ & 10 & $178 \pm 16^{* * *}$ \\
\hline $\begin{array}{l}\text { 9 } \alpha \text {-Fluoro-17 } \alpha \text {-methyl-17-hydroxy- } \\
\text { 4-androstene-3,11-dione }\end{array}$ & 10 & $129 \pm 8 * *$ \\
\hline $\begin{array}{l}\text { 9 } \alpha \text {-Fluoro-1 } 1 \beta, 17 \text {-dihydroxy-17-methyl- } \\
5 \beta \text {-androstan-3-one }\end{array}$ & 10 & $98 \pm 8$ N.S. \\
\hline $\begin{array}{l}9 \alpha \text {-Fluoro-17 } \alpha \text {-methyl-17-hydroxy- } \\
5 \beta \text {-androstane-3,11-dione }\end{array}$ & 10 & $111 \pm 9$ N.S. \\
\hline
\end{tabular}

*** $P<0.001 ; * * P<0.01 ;$ N.S. $=$ not significant.

$\dagger$ The uterus ratio was calculated as one hundred times the uterine weight $(\mathrm{mg})$ divided by the body weight $(\mathrm{g})$.

Table 3. Interruption of pregnancy in rats by FHA, fluoxymesterone and steroid U-6596

\begin{tabular}{|c|c|c|c|c|c|}
\hline \multirow{3}{*}{ Group } & \multirow{3}{*}{$\begin{array}{c}\text { No. of } \\
\text { rats }\end{array}$} & \multirow{3}{*}{$\begin{array}{c}\text { Steroids } \\
(5 \mathrm{mg} / 100 \mathrm{~g} \text { body } \\
\text { wt from Days } \\
3 \text { to } 7)\end{array}$} & \multicolumn{3}{|c|}{ Pregnancy } \\
\hline & & & \multirow{2}{*}{$\begin{array}{l}\text { Interruption } \\
(\%)\end{array}$} & \multicolumn{2}{|c|}{ Maintenance } \\
\hline & & & & No. of implantations/ & $\mid \begin{array}{c}\text { No. of fetuses } \mid \\
\text { rat } \uparrow\end{array}$ \\
\hline $\begin{array}{l}1 \\
2 \\
3 \\
4\end{array}$ & $\begin{array}{r}7 \\
11 \\
7 \\
6\end{array}$ &  & $\begin{array}{r}0 \\
100 \\
28 \\
0\end{array}$ & $\begin{array}{c}10.3 \pm 1.4 \\
\text { N.A. } \\
8.4 \pm 0.9 \text { N.S. } \\
8.8 \pm 0.6 \text { N.S. }\end{array}$ & $\begin{array}{c}9 \cdot 4 \pm 1 \cdot 2 \\
\text { N.A. } \\
3 \cdot 2 \pm 0 \cdot 7 * * * \\
3 \cdot 5 \pm 0 \cdot 8 * * *\end{array}$ \\
\hline
\end{tabular}

+ Mean \pm S.E. per rat bearing living fetuses on the 21 st day of pregnancy. $* * * P<0.001 ;$ N.S. $=$ not significant. N.A. $=$ not applicable.

\section{Histology of the target organs}

Microscopically, there were no apparent differences between the ovaries of treated and untreated rats: the follicles (some of which were atretic) showed various degrees of maturity. Corpora lutea were present in distinct stages of development. Increased magnification revealed no significant differences between the luteal cells of the control and FHA-treated rats. On Day 8 of pregnancy, the endometrium of the control animals consisted of moderately 


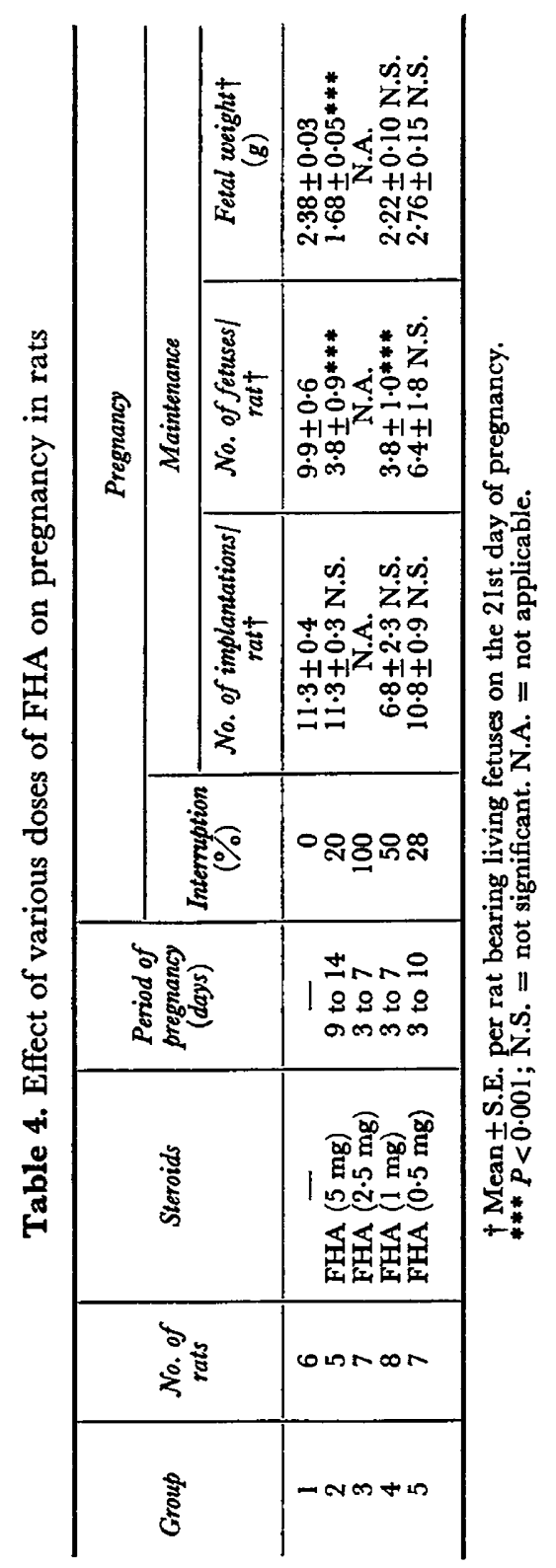






Fic. I. Lterus of (A) control and (B) FHA-treated rats killed on Day 8 of pregnancy. The decidual reaction seen in the controls is not evident in the treated animals. (PAS, $\times 120$ 
high columnar epithelium. The nuclei were basal in position. The stroma was slightly oedematous and was mainly composed of decidual cells (Pl. 1, Fig. 1A). By contrast, the endometrium of FHA-treated animals consisted of high cylindrical cells. Decidual cells could not be seen in the stroma, in which fibroblast-like elements were predominant (PI. 1, Fig. 1B).

Table 5. Effect of simultaneous treatment with FHA and progesterone or prolactin on pregnancy in rats

\begin{tabular}{|c|c|c|c|c|c|}
\hline \multirow{3}{*}{ Group } & \multirow{3}{*}{$\begin{array}{c}\text { No. of } \\
\text { rats }\end{array}$} & \multirow{3}{*}{ Steriods } & \multicolumn{3}{|c|}{ Pregnancy } \\
\hline & & & \multirow{2}{*}{$\begin{array}{l}\text { Interruption } \\
(\%)\end{array}$} & \multicolumn{2}{|c|}{ Maintenance } \\
\hline & & & & No. of implantations & $\begin{array}{c}\text { No. of fetuses/ } \\
\text { rat } *\end{array}$ \\
\hline 1 & 9 & - & 0 & $10 \cdot 9 \pm 1 \cdot 1$ & $9.5 \pm 0.9$ \\
\hline 2 & 8 & $\begin{array}{l}\text { FHA }(5 \mathrm{mg})+ \\
\quad \text { progesterone } \\
(6 \mathrm{mg})\end{array}$ & 100 & N.A. & N.A. \\
\hline 3 & 9 & 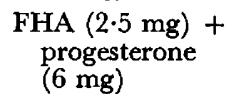 & 22 & $9 \cdot 4 \pm 1 \cdot 6$ N.S. & $7 \cdot 7 \pm 1.8$ N.S. \\
\hline 4 & 8 & $\begin{array}{c}\text { FHA }(5 \mathrm{mg})+ \\
\text { prolactin } \\
(2.5 \mathrm{mg})\end{array}$ & 100 & N.A. & N.A. \\
\hline 5 & 5 & $\begin{array}{l}\text { FHA }(2.5 \mathrm{mg})+ \\
\quad \text { prolactin } \\
(1 \mathrm{mg})\end{array}$ & 100 & N.A. & N.A. \\
\hline 6 & 5 & $\begin{array}{c}\text { FHA }(2.5 \mathrm{mg})+ \\
\text { prolactin } \\
(2.5 \mathrm{mg})\end{array}$ & 100 & N.A. & N.A. \\
\hline
\end{tabular}

N.S. = not significant. N.A. = not applicable.

* Mean \pm S.E. per rat bearing living fetuses on the 21 st day of pregnancy.

\section{DISCUSSION}

These experiments (Table 1) show that the three $9 \alpha$-fluoro-4-androsten-3-one derivatives (Groups 2, 3 and 4) interfere with pregnancy in the rat if given orally in doses of $5 \mathrm{mg} / 100 \mathrm{~g}$ body weight from Days 3 to 10 .

The effectiveness of the fluorosteroids was abolished (Group 5 versus Group 2), decreased (Group 6 versus Group 3) or unchanged (Group 7 versus Group 4) after substitution of $9 \alpha$-fluorine by $9 \alpha$-hydrogen, whereas antifertility activity was suppressed in all cases (Group 8 versus Group 3; Group 9 versus Group 4; Group 10) when the double bond was absent in position 4.

From the data summarized in Table 2, it is evident that fluorosteroid potency roughly parallels uterotrophic activity. In numerous investigations (Harper, 1969; Jacob \& Morris, 1969; Brooks, Steelman \& Patanelli, 1971), the postcoital antifertility effects of various natural and synthetic steroidal and non-steroidal compounds have been correlated with oestrogenicity (on the basis of uterotrophic activity). Bennett, Kendle, Vallance \& Vickery (1966), working on a series of steroids closely related in chemical structure, could not establish this relationship in all cases. 
The fact that all $5 \beta$-saturated androstane homologues are devoid of uterotrophic activity is consistent with the findings of Alloiteau (1965). This investigator reported that, to increase uterine weight and produce vaginal mucification, androstanes must necessarily possess a double bond in position 4 or 5 .

Our study showed that FHA was the most active among all the fluoroandrostanes tested (Table 3). Being devoid of androgenic properties (Rosemberg $\&$ Dorfman, 1958), it can be favourably compared with fluoxymesterone and steroid U-6596, which, respectively, have 9.5 and 8.5 times more androgenic potency than methyltestosterone (Lyster, Lund \& Stafford, 1956). Hence, FHA appears to be an interesting abortifacient compound. For an optimal effect, $2.5 \mathrm{mg}$ of this fluoroandrostane $/ 100 \mathrm{~g}$ body weight must be administered during the preimplantation phase of development. At lower dose levels, it significantly reduces the incidence of pregnancy and the number of fetuses per rat but exerts no teratogenic action. The compound even has some interceptive properties.

Progesterone, injected simultaneously with $2.5 \mathrm{mg}$ FHA, reversed the antiimplantation effect of the latter. This strongly suggests that FHA does not affect the viability of ova but acts through an hormonal disturbance.

A progesterone deficiency resulting from direct (luteolysis) or indirect (altered amounts of luteotrophic hormone) interference with the activity of the corpus luteum was not substantiated since: (I) the ovaries of the treated rats showed no histological evidence of modifications in luteal structure; and (2) exogenous prolactin (tested at two dose levels) did not counteract the antifertility effect of FHA.

The latter could also interrupt gestation by decreasing progesterone utilization at the target level. Although FHA is known to exert slight sodium-sparing activity (Rosemberg \& Dorfman, 1958; Selye, 1959), no report has been published on its antiprogestational properties. In our experiments, progesterone $(6 \mathrm{mg})$ abolished the abortifacient effect of $2.5 \mathrm{mg}$ but not of $5 \mathrm{mg}$ FHA. Steroids with a similar structure that inhibit the action of progesterone (given at or above a standard dose) are thought to act through competitive inhibition (Pincus, 1965). Hence, the possibility of competition in the uterus between progesterone and FHA cannot be ruled out.

The antiprogestational action of FHA could be related to its intrinsic 'oestrogenic' properties. Indeed, numerous reports suggest such a mechanism for the antifertility effect of several androstane derivatives (Marois, 1960, 1965; Harper, 1967, 1969). The present study confirms the observations of Rosemberg \& Dorfman (1958) that FHA has a mild uterotrophic effect in immature mice. This is commonly accepted as an indication of the oestrogenicity of a compound although such a test is not specific for oestrogens. Moreover, FHA is effective in preventing early pregnancy, and large doses have to be administered after nidation to cause fetal resorption. These effects are not unlike those of many oestrogens (Dreisbach, 1959; Saunders, 1965).

The mode of action of FHA is not yet clearly understood, but a few possibilities have been stated here. Further experiments are now in progress to elucidate the actual mechanism. 


\section{AGKNOWLEDGMENTS}

This work was supported in part by the Medical Research Council of Canada (Block Term Grant MT-1829), the Ministère des Affaires Sociales, Quebec, Succession J. A. DeSève, and the Colonial Research Institute, Freeport, Bahamas. The authors thank the companies listed in 'Materials and Methods' and Table 1 for their kind donations of compounds.

\section{REFERENGES}

Alloiteau, J. J. (1965) Action des oestrogènes et des androgènes sur le corps jaune de la ratte. Rev. europ. Endocr, 2, 155.

Bennett, J. P., Kendle, K. E., Vallance, D. K. \& Vickery, B. H. (1966) A comparison of the antifertility and hormonal activities of some new synthetic oestrogens. Acta endocr., Copenh. 53, 443.

Brooks, J. R., Steelman, S. L. \& Patanelli, D.J. (1971) Uterotropic and anti-implantation activities of certain resorcyclic acid lactone derivatives. Proc. Soc. exp. Biol. Med. 137, 101.

DreisBach, R. H. (1959) The effects of steroid sex hormones on pregnant rats. $\mathcal{F}$. Endocr. $18,271$.

Drill, V. A. (1960) SG-11927: an aldosterone-blocking agent. Pamphlet, Division of Biological Research, G. D. Searle \& Co. Chicago, Ill., U.S.A.

HARPER, M. J. K. (1967) Effects of androstenedione on pre-implantation stages of pregnancy in rats. Endocrinology, 81, 1091.

HARPER, M. J. K. (1969) Estrogenic effects of dehydroepiandrosterone and its sulfate in rats. Endocrino$\log y, \mathbf{8 4}, 229$.

JACOB, D. \& MORRIS, J. M. (1969) The estrogenic activity of postcoital antifertility compounds. Fert. Steril. 20, 211.

Lyster, S. G., Lund, G. H. \& Stafford, R. O. (1956) Androgenic and myotrophic properties of orally administered 9-fluoro-11-oxy-methyl-testosterones. Endocrinology, 58, 781.

Marois, M. (1960) Sur l'action novice exercée sur la gestation par certains stéroïdes. C. $r$. Séanc. Soc. Biol. 154, 1361.

Marors, M. (1965) Action de divers stéroïdes androgènes sur la ratte gestante, entière et ovariectomisée. Rev. europ. Endocr. 2, 163.

Pincus, G. (1965) The Control of Fertility, p. 128. Academic Press, New York,

Rosemberg, E. \& Dorfman, R. I. (1958) Biological activity of $9 \alpha$-fluoro-1 1 -hydroxy- $\Delta^{4}$-androstene3, I7-dione. Proc. Soc. exp. Biol. Med. 99, 336.

Rubin, B. L., Dorfman, A. S., Black, L. \& Dorfman, R. I. (1951) Bioassay of estrogens using the mouse uterine response. Endocrinology, 49, 429.

SAUNDERs, F. J. (1965) Effects on the course of pregnancy of norethynodrel with mestranol (Enovid) administered to rats during early pregnancy. Endocrinology, 77, 873.

SeLYe, H. (1959) Corticoid activity in the androstane series. Endocrinology, 65, 979.

Selxe, H., TACHE, Y. \& SzaBo, S. (1971) Interruption of pregnancy by various steroids. Fert. Steril. 22, 735.

TAGhE, Y. \& Selye, H. (1973) Activité antifertile de divers fluorostéroïdes chez le rat. Annls $A C F A S$, 40,121 .

TAche, Y., TAche, J. \& Selye, H. (1974) Antifertility effect of CS-1 in the rat. J. Reprod. Fert. $37,257$. 